\title{
JUBILEUSZ 100-LECIA \\ WYDZIALU PRAWA I ADMINISTRACJI \\ UNIWERSYTETU IM. ADAMA MICKIEWICZA. PRZEMÓWIENIE DZIEKANA PROF. ROMANA BUDZINOWSKIEGO NA UROCZYSTYM POSIEDZENIU RADY WYDZIALU
}

\author{
Poznań, 17 maja 2019 roku
}

Każdy jubileusz jest okazją do wspomnień, do podsumowania dotychczasowych dokonań i snucia planów na przyszłość. Jako społeczność Wydziału świętowaliśmy już kolejne okragłe rocznice, publikując z tej okazji okolicznościowe teksty. Uroczystości jubileuszowe wzmacniały naszą tożsamość, integrowały wokół spraw wspólnych, łączyły przeszłość z przyszłościa.

Dzisiejsze uroczyste posiedzenie Rady Wydziału z udziałem zaproszonych gości ma w sobie wiele symboliki. Dokładnie sto lat temu - 17 maja 1919 r. odbyło się pierwsze posiedzenie Rady Wydziału, na którym rozstrzygano trudne sprawy związane z początkiem działalności. Przywołanie tego dnia nie oznacza, że z nim należy wiązać początki Wydziału; wymienia się tu bowiem także inne daty, w tym między innymi 7 maja 1919 r., gdy został utworzony Uniwersytet z dwoma wydziałami: Wydziałem Filozoficznym i Wydziałem Prawa. Nie ulega wszakże wątpliwości, że wybór dzisiejszego dnia na uroczyste posiedzenie Rady Wydziału jest jak najbardziej uzasadniony.

Jubileusz 100-lecia skłania do szczególnych refleksji nie tylko ze względu na czas, jaki upłynął od chwili utworzenia Uniwersytetu i Wydziału. Dla nas jako wspólnoty Jubileusz stanowi powód do zasłużonej dumy i radości. Jesteśmy jedynym uniwersyteckim wydziałem z taką tradycja, wydziałem, który istnieje od początku powołania Uniwersytetu. Jesteśmy jednocześnie Wydziałem, który na tej 100 lat trwajacej drodze odnotował wiele sukcesów, a wśród swoich mistrzów i absolwentów miał i ma wiele osobistości, które są jego chluba.

Nie chciałbym, aby moje okolicznościowe przemówienie było zbyt formalne, suche, ograniczone do liczb i faktów, aczkolwiek i one są pożądane. Nie byłoby dobrze, gdyby było ono przepełnione emocjami. Trudno je przecież wyeliminować, jeśli mam świadomość współtworzenia historii Wydziału, a w pamięci różne wydziałowe wydarzenia z okresu już ponad półwiecza mojego zwiąku z Wydziałem; z Wydziałem, który przez minione 100 lat zmieniał się, niekiedy nawet bardzo dynamicznie. Ale... Mimo funkcjonowania w różnych warunkach, okresami bardzo trudnych, zmian struktury, otoczenia oraz przemienności kolejnych pokoleń badaczy, Wydział jest ciagle ten sam, choć nie taki sam.

Motywem mojego wystapienia niech będzie hasło, które towarzyszy nam od 5 lat, to jest od 95. rocznicy utworzenia Wydziału, a mianowicie: Myślac 
o przyszłości, nie zapominamy o przeszłości. Każdy może je odczytać na banerze znajdujacym się na Collegium Iuridicum Novum, taki też tytuł nosi nasza Księga Jubileuszowa. Jest więc stosowny czas, by sięgnać do przeszłości, pokazać teraźniejszość i odnieść się do przyszłości.

\section{Przeszłość}

Rozpocznę zatem od przeszłości, która żyje w nas, z którą stykamy się na każdym kroku. Przeszłość to nasza, jak się czasami mówi, wartość dodana - nasi mistrzowie i absolwenci, ich dokonania wpisane w jakże różne dzieje historyczne, ale też ciąła budowa potencjału Wydziału i jego prestiżu. Każdy z nas tu obecnych tę przeszłość odnosi najczęściej do pamięci swojego pokolenia, a zatem - w zależności od wieku - obejmuje bliższą lub dalszą perspektywę czasową. Ta najdalsza, nieobjęta już pamięcią osób żyjących, jest na szczęście zapisana, a więc łatwa do odtworzenia. Warto i do niej nawiąać, zwłaszcza że odwoływanie się do przeszłości, kultywowanie tradycji, zawsze było, i nadal jest, czynnikiem integrującym społeczność Wydziału. O przeszłości, to jest o pierwszych latach Wydziału, będzie jeszcze dzisiaj mowa, jest ona też uwzględniona w Księdze Jubileuszowej oraz w zamieszczonej w niej historii poszczególnych katedr czy zakładów. Dlatego zwrócę uwagę na niektóre aspekty.

Wydział już od początku miał szczęście do kadry profesorskiej. A wszystko zaczęło się od czterech profesorów w chwili powołania Wydziału: Antoniego Peretiatkowicza (pierwszego dziekana, późniejszego rektora i prorektora), Jana Rutkowskiego, Tadeusza Brzeskiego i Zygmunta Lisowskiego (również późniejszego rektora i prorektora). Jak więc widać, nasi profesorowie nie tylko organizowali Wydział i uruchamiali pierwszy rok zajęć, ale również współorganizowali cały Uniwersytet jako rektorzy i prorektorzy. Stosunkowo szybko udało się zatrudnić dalszych pracowników naukowych (do 1939 r. już 54). Pojawiły się znakomite osobistości, które stały się nauczycielami naszych (to jest młodszego pokolenia) nauczycieli, stali się mistrzami naszych mistrzów. Wymienię przykładowo profesorów: Alfreda Ohanowicza, twórcę poznańskiej cywilistyki; Czesława Znamierowskiego, który stworzył podstawy poznańskiej szkoły teorii prawa, rozwiniętej i ugruntowanej później przez prof. Zygmunta Ziembińskiego, czy prof. Edwarda Taylora.

Profesorowi Wydziału nie stronili także od innej działalności. Założony przez prof. Peretiatkowicza w 1921 r. „Ruch Prawniczy i Ekonomiczny” (później także Socjologiczny) cieszy się także obecnie zasłużoną renomą. Profesor Kasznica pełnił również funkcję rektora Uniwersytetu. Wielu profesorów było mocno zaangażowanych $\mathrm{w}$ działalność poza macierzystą Uczelnią. Wspomnę choćby profesorów: Jana Rutkowskiego, Alfreda Ohanowicza, Bohdana Winiarskiego czy Bronisława Stelmachowskiego, ojca późniejszego prof. Andrzeja Stelmachowskiego (wybitnego cywilisty i marszałka Senatu po zmianach ustrojowych w 1989 r.). 
Druga wojna światowa przerwała normalne funkcjonowanie i rozwój Wydziału. Aktywność badawcza i dydaktyczna była prowadzona w konspiracji, także za granica, ale wielu profesorów nie przeżyło tych trudnych czasów. Jeszcze nie zakończyły się działania wojenne, a już przystapiono do odbudowy Wydziału i uruchomienia studiów. Znowu o sile Wydziału i jego prestiżu przesądziła aktywność badawcza jego kadry naukowej. Wymienię choćby późniejszych profesorów, jak: Zygmunt Konrad Nowakowski, Kazimierz Kolańczyk, Zdzisław Kaczmarczyk, Marian Zimmermann, Zbigniew Janowicz, Zbigniew Leoński, Wiktor Jaśkiewicz, Zbigniew Radwański, Zygmunt Ziembiński i wielu, wielu innych.

Studiując na przełomie lat sześćdziesiątych i siedemdziesiątych, ja i kilka innych roczników studentów mieliśmy to szczęście, że naszymi mistrzami byli naukowcy, którzy swoje ostrogi naukowe zdobywali pod kierunkiem uznanych profesorów z okresu międzywojnia. To oni kształtowali również naszą formację naukowa, sposób uprawiania nauki i postrzeganie świata. Wymienię dwie osoby symbole: prof. Zygmunta Ziembińskiego i prof. Zbigniewa Radwańskiego.

Niestety, bardzo wielu profesorów i pracowników Wydziału, niezwykle zasłużonych dla naszego rozwoju, nie ma już wśród nas. Nie znaczy to, że nie istnieją w naszej wdzięcznej pamięci, ich dokonania przewijają się w naszej pracy naukowej. Utrwalamy ich osiagnięcia w różnych publikacjach. Natomiast z wdzięcznością i z podziękowaniem dla autora wspomnę tu księgę opracowana przez prof. Henryka Olszewskiego - Ludzie Uniwersytetu w mojej pamięci: przywołuje ona postacie i dokonania nie tylko pracowników naukowych, ale i pracowników administracyjnych. W pokoju pamięci Wydziału (Sali 1.1) znajdują się już 102 portrety naszych zmarłych mistrzów.

Drugi aspekt, nie mniej ważny, stanowiący wszakże przedmiot naszych codziennych działań, to studenci, późniejsi absolwenci. Do 1939 r. mury naszego Wydziału opuściło nieco ponad 2 tysiące absolwentów, a do dzisiaj - ponad 46 tysięcy. Jest to ogromna liczba osób dobrze przygotowanych do wykonywania nie tylko zawodu prawnika, ale do różnych zawodów, niekiedy bardzo dalekich od wykształcenia zdobytego na naszym Wydziale. Absolwenci sa chlubą naszego Wydziału, pełnili i pełnia najbardziej zaszczytne funkcje w życiu publicznym, sprawowali bądź sprawują najwyższe urzędy w państwie. Jutro, przy okazji zjazdu absolwentów, wrócę jeszcze do dokonań tych, którzy sa dowodem naszej działalności, uzasadniają ja, dostarczają nam wielu satysfakcji - sa powodem do dumy i radości.

\section{Teraźniejszość}

Powinnością urzędującego dziekana jest przynajmniej naszkicowanie współczesnego stanu Wydziału, jego osiagnięć. Problemy pozostawiam raczej na kolejną roboczą naradę. Wydział znajduje się między przeszłością a przyszłościa. Przeszłość jest znana. To wspomniany rozwój na przestrzeni 100 lat, 
sukcesy na różnych polach, czasem może i niepowodzenia, ale przede wszystkim to nasi mistrzowie, którzy mogą dla nas stanowić, zapewne też stanowia, wzór, choć czasem trudny, to godny naśladowania.

Należy jednak zauważyć, że by znaczyć coś w nauce, nie wystarczy skrycie się pod aureolą mistrza; powiedzenie, że moim mistrzem był jeden z naszych wybitnych profesorów, nie przesądza o wielkości jego następcy, czasami może wywoływać refleksje idące w zupełnie przeciwnym kierunku. Jak napisał prof. Jan Zdzitowiecki, były długoletni kierownik Katedry Prawa Finansowego, autorytetu mistrza się nie dziedziczy. To prawda. Każdy z osobna musi zapracować na własny sukces, co też przekłada się na osiagnnięcia Wydziału. Wszyscy zaś razem pracujemy na sukces naszej wspólnoty wydziałowej i całego Uniwersytetu.

Rozpocznę od przytoczenia niektórych danych liczbowych, by zobrazować obecny stan Wydziału. Zatrudniamy łącznie 186 pracowników, w tym 136 pracowników naukowych (zatem więcej niż w przeszłości, co nie znaczy, że liczebność kadry odpowiada naszym potrzebom). W gronie pracowników naukowych mamy 23 profesorów tytularnych, 40 doktorów habilitowanych na stanowisku profesora UAM i 17 doktorów habilitowanych na stanowisku adiunkta. Warto odnotować, że od 2012 r. - 15 osób otrzymało tytuł profesorski, a 10 postępowań jest w toku. Nigdy tylu nie było, co odnotowuję jako sukces. W tym też okresie 46 osób uzyskało stopień doktora habilitowanego, a w toku jest 6 postępowań - w przeszłości też nie było tylu awansów naukowych tego rodzaju. Zatrudniliśmy 38 doktorów na stanowiska adiunktów. W tym samym okresie pożegnaliśmy 15 osób z grona profesorów. Nastapiła więc zmiana generacji; wśród tak zwanych samodzielnych pracowników naukowych (co widać na posiedzeniach Rady Wydziału) dominują osoby rozpoczynające karierę w połowie lat dziewięćdziesiątych i później (niektórzy mają już tytuł profesora). Nastapiło więc odmłodzenie kadry naukowej niemające swego odpowiednika w historii. Nasze działania wspiera Biblioteka Wydziałowa, niezwykle bogata, posiadająca bardzo liczne publikacje zagraniczne, zarówno w formie monografii, jak i czasopism, a także pracownicy administracyjni, raczej w młodszym wieku, bez których nie moglibyśmy normalnie funkcjonować.

Zatem nasz potencjał jest naprawdę znaczący. Czy dobrze wykorzystywany? Uważam, że tak, choć zawsze można by powiedzieć, że mogłoby być jeszcze lepiej. Nie narzekam. Na polu szeroko rozumianej działalności naukowej osiąnęliśmy wiele sukcesów - w ocenie instytucjonalnej Polskiej Komisji Akredytacyjnej otrzymaliśmy ocenę bardzo dobrą (przy braku uwag krytycznych), wysokie miejsca zajmujemy w rankingach prowadzonych przez różne publikatory. Ale... Jako jedynemu wydziałowi prawa w Polsce w ostatniej ocenie parametrycznej w 2017 r. Ministerstwo Nauki i Szkolnictwa Wyższego przyznało kategorię naukową A plus. Wyróżnia nas ona także w ramach naszej Uczelni (oprócz nas jeszcze tylko dwa wydziały mają taką kategorię). Nie można więc powiedzieć, że nasz Wydział stoi tylko dydaktyką (w przeszłości tak mówiono), choć i ona jest ważna, jest też naszą misją.

Kategoria A plus stanowi urzędowe potwierdzenie naszych osiagnięć, a jednocześnie ogromne wyzwanie na przyszłość. Sukces to olbrzymi, który 
oprócz zasłużonej dumy przyniósł nam zwiększone środki finansowe wykorzystywane na dalszy rozwój potencjału badawczego, choćby na finansowanie grantów na staże badawcze za granica czy finansowanie wyłanianych w drodze konkursów zespołów badawczych. Oczywiście ten sukces nie pojawił się znikąd, zapracowaliśmy na niego wszyscy (choć może w niejednakowym stopniu), jednocząc wysiłki, integrując się wokół spraw ważnych dla Wydziału.

Imponująca jest liczba publikacji naukowych, w tym monografii i artykułów. Zapewne znacznie większa niż w poprzednich okresach w przeszłości, co nie znaczy samo przez się, że obecnie ich poziom naukowy jest niższy. Jest, tak jak poprzednio, zróżnicowany. Dzisiaj jednak znacznie łatwiej o dostęp do literatury, także obcej, do zagranicznych staży badawczych, a i sam proces publikacji uległ znacznemu skróceniu. Nasza działalność naukowa znacznie wykracza poza tradycyjne tematy; podejmujemy nowe, innowacyjne problemy badawcze związane $\mathrm{z}$ funkcjonowaniem gospodarki czy wymiaru sprawiedliwości, w coraz szerszym zakresie współpracując z nauką zagraniczna.

Niewątpliwie bardzo cieszą coraz liczniejsze publikacje naszych pracowników w językach obcych (otwarta i kontynuowana jest seria monografii w języku angielskim), a także za granica. Dzięki temu jesteśmy widoczni, znani i cieszymy się coraz większym uznaniem nie tylko w Europie, ale na całym świecie. Uzyskujemy granty na badania nie tylko ze środków instytucji polskich, ale również europejskich. Zorganizowaliśmy wiele wydarzeń, w tym konferencji, z udziałem przedstawicieli nauki zagranicznej, gościliśmy znakomitych profesorów z zagranicy i sami prowadziliśmy wykłady poza granicami naszego kraju. Ta ożywiona współpraca zagraniczna również legła u podstaw wyróżnienia kategorią naukową A plus.

Zapewne nie bez przyczyny światowa organizacja prawników agrarystów (Unione Mondiale degli Agraristi Universitari) powierzyła naszemu Wydziałowi organizację w 2018 r. - po raz pierwszy w Polsce - XV Światowego Kongresu Prawników Agrarystów, a Europejski Komitet Prawa Rolnego (Comiteé Européen de Droit Rural), również po raz pierwszy - organizację w 2019 r. XXX Europejskiego Kongresu i Kolokwium Prawa Rolnego, ważnego z punktu widzenia naszego kraju choćby ze względu na zaplanowane seminarium dotyczące przyszłości Wspólnej Polityki Rolnej po 2020 r. i udział osobistości z instytucji unijnych. Przewidujemy więcej takich wydarzeń w najbliższym czasie, zachęcamy do ich organizacji i je wspieramy.

$\mathrm{Na}$ Wydziale funkcjonuje kilka czasopism, w tym „Ruch Prawniczy, Ekonomiczny i Socjologiczny”, czasopismo najstarsze, założone jeszcze przed wojna, oraz „Czasopismo Prawno-Historyczne”. Oba publikatory cieszą się zasłużona renomą w nauce polskiej. Uzyskały one, a także „Przegląd Prawa Rolnego" oraz „Adam Mickiewicz University Law Review/ Przegląd Prawniczy UAM”, ministerialna pomoc de minimis, co oznacza, że publikowane tam artykuły będą wysoko punktowane. Jest to ważne z punktu widzenia przyszłej oceny parametrycznej Wydziału.

Jeśli ekonomiści mówią i piszą że nauka ekonomii jest piękna, to niewątpliwie nauki prawne też są piękne. One bowiem dają możliwość oddziaływania na rzeczywistość przez stanowienie i stosowanie prawa, które przecież wyraża 
pewne powszechnie akceptowane wartości. Uprawiający nauki prawne maja świadomość misji wykonywanej dla społeczeństwa, dla państwa, właśnie dla ich dobra. Oczywiste zatem jest, że sa oni często angażowani do sprawowania różnych funkcji publicznych. Pracownicy czy seniorzy Wydziału piastowali i piastują ważne stanowiska w różnych organach, nie tylko sądowych. Dzięki tej działalności Wydział jest obecny, jest dostrzegany na zewnątrz, ma większe możliwości wpływu na otaczającą nas rzeczywistość.

Jednocześnie nauki prawne są bliskie polityce. Nic więc dziwnego, że środowiska prawnicze, także naukowe, wyrażaja swoje stanowisko wobec różnych zjawisk życia publicznego. Takie też stanowisko, w sposób stanowczy i jednoznaczny, sformułowała w swoim czasie także nasza Rada Wydziału. Na szczęście dla codziennej pracy nasz Wydział nie jest podzielony, nie występuja dyskusje, które do niczego by nie prowadziły; potrafimy skoncentrować się, zjednoczyć wokół spraw, które łączą - właśnie dla dobra Wydziału i Uniwersytetu.

Kształcenie jest naszą kolejną misja, misją realizowaną nie w celu wypracowania określonej liczby godzin dydaktycznych uzasadniających uruchomienie kolejnych etatów. To jest też nasza odpowiedź na zapotrzebowanie społeczne, służenie rozwojowi społeczeństwa i państwa. Prowadzimy studia na sześciu kierunkach (prawo, prawno-ekonomiczny, administracja, prawo europejskie, zarządzanie i prawo w biznesie oraz prawo jako wspólny kierunek z Uniwersytetem Europejskim Viadrina we Frankfurcie nad Odra), staramy się o uruchomienie studiów w języku angielskim - European Legal Studies. Nasz Wydział zalicza się niewątpliwie do czołówki wydziałów UAM, gdy idzie o liczbę studentów stacjonarnych i niestacjonarnych. Nie mamy problemów z naborem, sami ograniczyliśmy limity przyjęć na I rok studiów, mając na uwadze tak zwany wskaźnik jakości dydaktycznej oraz potrzebę zwiększenia aktywności badawczej. Obecnie studiuje u nas około 4000 studentów.

Od trzech lat kilka naszych kierunków studiów (to jest: prawno-ekonomiczny, prawo i zarządzenie w biznesie oraz prawo jako kierunek prowadzony wspólnie z Viadrina) jest wyróżnianych w ramach ogólnopolskiego Konkursu „Studia z przyszłościa”. Zdobywamy kolejne, coraz wyższej rangi, certyfikaty potwierdzające, że te kierunki są dobrze dostosowane do wyzwań współczesnego rynku pracy, o wysokim stopniu użyteczności praktycznej. Odnotować należy czołowe miejsca prowadzonych przez nas studiów w różnych rankingach. Powodem do dumy jest coraz wyższy wskaźnik zdawalności na aplikacje korporacyjne. Według danych Ministerstwa Sprawiedliwości awansowaliśmy z miejsca VIII sprzed dziesięciu laty na miejsce II. Właśnie nasi absolwenci z 2018 r. zajęli II miejsce, zostawiając w tyle renomowane wydziały prawa. Również gdy idzie o zdawalność na aplikację sądową i prokuratorska - według danych Krajowej Szkoły Sądownictwa i Prokuratury - w ostatnim rankingu za 2018 r. zajęliśmy II miejsce. Świadczy to dobrze o naszych programach studiów i ich realizacji, ale również, a może zwłaszcza, o dobrej, samodzielnej pracy absolwentów, którzy muszą powtórzyć wcale niemały materiał. Zachęcamy studentów do intensywnej powtórki, organizujac spotkania informacyjne na temat aplikacji, także z udziałem przedstawi- 
ciela z Ministerstwa Sprawiedliwości (dwa razy), a ostatnio także Krajowej Szkoły Sądownictwa i Prokuratury.

Cieszy nas zaangażowanie studentów na różnych polach aktywności. Na Wydziale funkcjonuje ponad 30 studenckich kół naukowych, ożywiona jest ich działalność konferencyjna, nawet bardziej widoczna niż aktywność w tym zakresie samych pracowników. Studenci są włączani do prowadzonych na Wydziale projektów badawczych. Swoje pierwsze prace naukowe publikuja w czasopismach studenckich czy cyklicznych pracach zbiorowych (jak Zeszyty Studenckich Kół Naukowych naszego Wydziału). Najlepsze prace magisterskie wyróżniamy w ramach corocznego Konkursu im. Prof. Kazimierza Kolańczyka, jak również zdobywają one nagrody w licznych innych konkursach realizowanych w skali ogólnopolskiej.

Wielu studentów wyjeżdża - w ramach studiów - za granicę (dodam, że w ramach programu Erasmus współpracujemy z prawie 80 uniwersytetami z różnych państw). Przyjmujemy również studentów zagranicznych i prowadzimy dla nich zajęcia w języku obcym. Mogę powiedzieć z całą odpowiedzialnościa, że czołówka studentów jest znacznie lepsza niż w przeszłości, zna nie jeden, lecz nawet kilka języków obcych, ma doświadczenia z pobytów za granica, zdobywa kwalifikacje praktyczne w różnych kancelariach czy instytucjach już w czasie studiów. Nic więc dziwnego, że i dzisiejsi absolwenci zajmują liczącą się, godną pozycję w pracy zawodowej, dając dobre świadectwo Wydziałowi, na którym studiowali.

My zresztą ze swej strony staramy się wspierać różne inicjatywy studenckie służące integracji braci studenckiej, a także różne formy zespołowego działania, czy to w postaci samorządu, czy innych organizacji, jak na przykład ELSA. Jako że nie samą nauką student żyje (okres studiów uchodzi nie bez przyczyny za najpiękniejszy etap życia), wspieramy też te działania, które służą rozwojowi kultury studenckiej. Od wielu lat odbywają się w Collegium Iuridicum Novum koncerty studenckie Cin-ART. Okazuje się, że studenci naszego Wydziału często ukończyli szkoły muzyczne, a nawet są studentami akademii muzycznych. Wspieramy też różne imprezy studenckie, łącznie z tak zwanym Wielkim Grillowaniem.

Prowadzimy studia doktoranckie, stacjonarne i niestacjonarne. Stopień doktora od 2012 r. uzyskało 130 doktorantów, a w ostatnich dwóch latach - 28. Studia doktoranckie przygotowuja do pracy naukowej, wiele rozpraw doktorskich zostało wyróżnionych nagrodami w różnych ogólnopolskich konkursach, między innymi: „Państwa i Prawa”, Konkursie im. Profesora Zbigniewa Radwańskiego czy Konkursie im. Profesora Andrzeja Stelmachowskiego. Doktoranci często uzyskują granty badawcze wykorzystywane na staże naukowe w kraju i za granica, mają też własne czasopismo naukowe „Adam Mickiewicz University Law Review/ Przegląd Prawniczy UAM" (ostatnio wydawany w języku angielskim i zyskujący coraz wyższą rangę). Nie wszyscy doktorzy uzyskują etat adiunkta, ale przecież kształcenia doktorantów zostało oderwane od (wyłącznie) potrzeb kadrowych Wydziału.

Utrzymujemy szeroką współpracę z otoczeniem społecznym. Kilkuletnia już tradycję mają wykłady dla uczniów szkół średnich (zwłaszcza licealistów) 
organizowane przez naszych pracowników i doktorantów. Prowadzimy je przy współpracy z Kuratorium Oświaty w naszym Collegium. Z wieloma liceami podpisaliśmy deklaracje o współpracy, odwiedzamy je też, wygłaszając wykłady, przybliżając młodzieży elementarne wiadomości o prawie, a przy okazji i o naszym Wydziale. Studenci pod opieką pracowników udzielają porad prawnych w ramach Kliniki Prawa. Interesariusze zewnętrzni biorą udział w ocenie naszych programów studiów, wpływają na jakość kształcenia. Organizujemy wykłady otwarte nie tylko dla społeczności Uniwersytetu, ale miasta i regionu, w tym wykłady współorganizowane przez Stowarzyszenie Absolwentów Uniwersytetu im. Adama Mickiewicza w Poznaniu, któremu przewodniczy wicemarszałek województwa wielkopolskiego Wojciech Jankowiak.

Bardzo rozbudowane są nasze więzi z otoczeniem gospodarczym. Zapewniają nam one możliwość realnego wpływu na funkcjonowanie różnych instytucji, ale i one oddziałują na naszą działalność. Instytucjonalną formą tej współpracy jest między innymi utworzona w ubiegłym roku Rada Biznesu i Nauki Wydziału Prawa i Administracji. Podpisujemy deklaracje o współpracy z różnymi organizacjami gospodarczymi. Jesteśmy otwarci na kontakty z naszymi absolwentami, wspieramy zjazdy poszczególnych roczników studiów, bierzemy udział w uroczystościach odnowienia tytułu magistra tych absolwentów, którzy ukończyli studia przed 50 laty. Wreszcie utworzyliśmy Stowarzyszenie Absolwentów i Przyjaciół Wydziału Prawa i Administracji w celu zachowania więzi absolwentów z Wydziałem. To tylko niektóre przykłady naszych relacji z otoczeniem społecznym i gospodarczym.

Podejmujemy też liczne inicjatywy zmierzajace do integracji społeczności Wydziału, poza realizacjązadań naukowych, dydaktycznych czy organizacyjnych związanych z funkcjonowaniem Wydziału i Uczelni. Kontynuujemy wydziałowe pikniki, od kilku lat wzbogacone o mecze piłki nożnej naszych pracowników z pracownikami Wydziału II Lekarskiego poznańskiego Uniwersytetu Medycznego (ostatni mecz wygraliśmy). Widoczna jest też nasza współpraca z innymi uczelniami, jak: Uniwersytet Ekonomiczny, Uniwersytet Artystyczny (cykliczne wystawy prac) i wspomniany Uniwersytet Medyczny. Nie udało się nam zorganizować balu wydziałowego (jak na przełomie lat siedemdziesiątych i osiemdziesiatych), ale może młodsze pokolenie już nie pała taką miłością do walca czy tanga. Te przykłady naszej działalności można by dalej kontynuować, są one bliżej opisane w Księdze Jubileuszowej.

Angażując się w bieżącą działalność, nie zapominamy o naszych mistrzach i nauczycielach, o naszych seniorach. Sa zapraszani na posiedzenia Rady Wydziału. Cieszymy się, że z naszej inicjatywy mogliśmy uhonorować wielu seniorów godnościami czy medalami uniwersyteckimi: Palmae Universitatis Studiorum Posnaniensis, uroczystym odnowieniem doktoratu czy wyróżnieniem medalem Homini Vere Academico. Dwóch naszych znakomitych mistrzów, nauczycieli nauczycieli, posiada już aule swego imienia: prof. Zygmunt Ziembiński i prof. Zbigniew Radwański. Każdy z nas ma bowiem w pamięci, a może i w sercu, wdzięczność dla swego nauczyciela i mistrza. Jest dla nas ogromnym zaszczytem, że możemy i dziś, w trakcie tego uroczystego posiedzenia Rady Wydziału, gościć naszych seniorów. W imieniu włas- 
nym, a także całej społeczności wydziałowej dziękuję wam, drodzy profesorowie, za to że jesteście z nami, za wasz wkład w rozwój Wydziału, wyrażam uznanie dla waszych osiagnięć oraz składam życzenia zdrowia i wszelkiej pomyślności.

\section{Przysztość}

W dniu jubileuszu nie można pominąć choćby krótkiego odniesienia do przyszłości, a tu pokazania kontynuacji, ale także tego, co na nas wymusza rzeczywistość, czyli modernizacji. Dlatego określając program działań na lata 2012-2016 i 2016-2020, użyłem obrazowego określenia „między kontynuacja a modernizacją" Ta pierwsza jest zrozumiała i nie wymaga komentarza. Wypływa ona też ze Strategii rozwoju Wydziału na lata 2011-2019, jego misji i wizji. Ta druga - modernizacja - wymuszona jest przez obecną regulację oraz rzeczywistość. Wiążą się z nią liczne niepewności związane choćby z wdrażaniem nowej ustawy o szkolnictwie wyższym i nauce, która wprowadziła znaczące zmiany. W nowe stulecie wchodzimy wprawdzie jako Wydział, ale nie będący już (od 1 października 2019 r.) podstawową jednostką organizacyjna Uniwersytetu, lecz jednostką szkoły dziedzinowej, zmienił się też status dziekana, inaczej będą prowadzone studia, także doktoranckie.

Jesteśmy otwarci na nowe wyzwania, zamierzamy należycie wykorzystać nasze możliwości badawcze i dydaktyczne, a także w zakresie współpracy z zagranica oraz z otoczeniem społecznym i gospodarczym. Zasadniczym celem podejmowanych działań będzie dalsze wzmocnienie pozycji Wydziału, jak też utrzymanie jej w tych sferach, w których dziś zajmujemy czołowe miejsce w kraju (w tym zachowanie kategorii A plus, co może nie być łatwe).

Troska o utrzymanie pozycji Wydziału, jego rangi i dalszy rozwój wymaga umiejętnego połączenia tego, co jest wyrazem tradycji, a tu między innymi relacji mistrz-uczeń, autorytetu wynikającego z zaangażowania w pracę naukowa, dydaktyczną i organizacyjna czy uznanych wartości uniwersyteckich z tymi wymogami, które są znakiem obecnych czasów - oceną parametryczną, punktacją za publikacje naukowe czy ocena pracowników. Wydział jest pewna wspólnotą złożona z mniejszych jednostek. Właśnie z punktu widzenia zapewnienia wysokiej pozycji Wydziału należy realizować politykę zrównoważonego rozwoju, dbajacc też o to, by Wydział miał charakter uniwersytecki, a nie zawodowy.

Dzisiejszy Jubileusz 100-lecia Wydziału nie zamyka jego historii, otwiera nowe stulecie, ale już w zmienionych realiach. Bądźmy nadal liderem w szerzeniu i propagowaniu tradycyjnych wartości akademickich we współczesnym świecie, podejmujmy nowe wyzwania badawcze, bądźmy otwarci na ambitne oczekiwania pracowników i studentów, silnie powiązani z naszymi absolwentami, mocno związani z otoczeniem społecznym i gospodarczym i pracujmy też na jego rzecz. 
Dziś jest doskonała okazja, by oddać cześć, wyrazić szacunek i podziękowanie tym wszystkim, którzy przyczynili się do rozwoju Wydziału, jego uznania w kraju i za granica. Z uznaniem i z szacunkiem odnoszę się do zasług wszystkich osób zaangażowanych w rozwój Wydziału, zarówno pracowników naukowych, jak i administracyjnych. Z uznaniem, szacunkiem i podziwem odnoszę się również do zasług absolwentów, którzy są naszymi ambasadorami w różnych środowiskach zawodowych. Moją miła powinnością jest też podziękowanie wszystkim kolejnym zespołom rektorskim, które miały na uwadze dobro Wydziału i którym zawdzięczamy obecny potencjał i perspektywy rozwoju w przyszłości. U progu nowego stulecia trzeba zrobić wszystko, by ten potencjał należycie wykorzystać i zbudować trwałe podstawy dalszego rozwoju, uwzględniając także nie do końca zaspokojone nasze potrzeby infrastrukturalne. Liczę na dalszą życzliwość i wsparcie tych wszystkich osób i instytucji, którym dobro naszego Wydziału i Uniwersytetu leżało i leży na sercu.

Życzmy sobie dalszych sukcesów na kolejne 100 lat. 